\title{
Türkiye'deki iç mimarlık firmalarının ahşap malzemeleri kullanımı ve tercih düzeyleri
}

\author{
Selim Değirmentepe ${ }^{1 *}$ (D), Mehmet Çolak ${ }^{2}$ (iD
}

\section{$\ddot{O} \mathbf{z}$}

$\mathrm{Bu}$ çalışmada, iç mimarlık firmalarının, iç ve dış mekânlarda ahşap malzemeleri mobilya ve yapı malzemesi olarak kullanımları ve tercihleri araştırılmıştır. Bu araştırmanın amacı; iç mimarlık firmalarının ahşap malzemeler ile ilgili görüşlerini ve ahşap malzeme kullanma eğilimlerini belirlemektir. Araştırma kapsamında; iç mimarlık firmaları üzerine bir araştırma yapılması amacıyla basit tesadüfi örneklem yöntemi ile tespit edilen ve Türkiye genelini temsil edebilecek olan İstanbul, Ankara ve İzmir illeri seçilmiştir. 272 iç mimarlık firmasının yöneticilerine anket uygulaması gerçekleştirilmiş ve anket tekniği ile katılımcılar tarafından soruların cevaplandırılması üzerine elde edilen veriler analiz edilmiştir. Sonuç olarak; araştırma yapılan işletmelerin, ahşap malzemelerin kullanım olanaklarının yüksek olduğu düşüncesine yeteri kadar katılım sağlamadığ 1 belirlenmiştir. Malzeme tercihi durumlarına bakıldığında, iç mekânlara kıyasla diş mekânlarda ahşap malzemeleri hem mobilya hem de yapı malzemesi olarak işletmeler tarafindan daha düşük seviyede tercih edildiği tespit edilmiştir. İç ve diş mekânlarda hem mobilya hem de yapı malzemesi olarak en çok masif ahşap malzemenin tercih edildiği görülmüştür.

Anahtar kelimeler: Ahşap malzemeler, İç mekân, Dış mekân, Mobilya, Yap1

\section{The use of wood materials and preference levels of interior architecture firms in Turkey}

\begin{abstract}
In this study, the use and preferences of wood materials of interior architecture firms as furniture and building materials in interior and outdoor spaces were investigated. The aim of this research is to conduct a research on interior architecture firms in order to determine the opinions of interior architecture firms about wood materials and their tendency to use wood materials. In the scope of the research; the provinces of Istanbul, Ankara and Izmir, which were determined by the sampling method and represent the whole of Turkey, were selected. The managers of 272 interior design offices were applied the questionnaire and the data obtained from the participants were analysed. As a result; it has been noted that the enterprises didn't agree with the idea of having a high potential for the use of wooden materials. Considering the material preference status of the enterprises; it was also found that wooden materials were not highly preferred in outdoor spaces both for furniture and building materials compared to interior spaces. It has been concluded that solid wood was highly used as furniture and building material in interior and outdoor spaces.
\end{abstract}

Keywords: Wooden materials, Interior, Outdoor, Furniture, Building

Makale tarihçesi: Geliș:20.10.2021, Kabul:19.12.2021, Yayınlanma:27.12.2021, *e-posta: sdegirmentepel@ bingol.edu.tr, ${ }^{1}$ Bingöl Üniversitesi, Teknik Bilimler MYO, Tasarım Bölümü, Bingöl/Türkiye, ${ }^{2}$ Muğla Sitk1 Koçman Üniversitesi, Teknoloji Fakültesi, Ağaç İssleri Endüstri Mühendisliği Bölümü, Muğla/Türkiye,

Atıf: Değirmentepe S., Çolak M., (2021), Türkiye'deki iç mimarlık firmalarının ahşap malzemeleri kullanımı ve tercih düzeyleri, Mobilya ve Ahşap Malzeme Araştırmaları Dergisi, 4 (2), 193-204,

DOI: $10.33725 / \mathrm{mamad} .1012526$ 


\section{Giriş}

Ahşap malzemeler; karakteristik özelliklerinde hiç bir değişik yapılmadan elde edilen doğal ahşap ya da masif ahşap malzeme ve teknolojiden faydalanılarak karakteristik özellikleri değiştirilerek daha iyi bir kullanım için geliştirilen yapay ahşap ya da ahşap esaslı malzeme olarak iki farklı şekilde elde edilmekte ve mobilya ve yapı elemanları olarak kullanılmaktadırlar (Kartal, 2015).

Genel anlamda mobilya ve yapılarda kullanılan malzemeleri; ahşap malzemeler, metal malzemeler, tekstil ürünleri, doğal ve suni deri, plastik malzemeler, doğal taş ve kompozit malzemeler olarak siralayabiliriz (Kurtoğlu ve Sofuoğlu, 2013).

İç ve diş mekânlarda, ahşap ve ahşap esaslı malzemelerden birçok değişik amaçlarla faydalanılmaktadır. Ahşap malzemeler gerek mobilyalarda gerekse yapı malzemelerinde kullanım imkânları oldukça yüksek malzemelerdir (Çolak ve Değirmentepe, 2020).

Ahşap malzeme tarih boyunca hayatımızda yer alan bir malzemedir. Gerek mobilya gerekse yapı sektöründe büyük potansiyele sahip bir malzemedir. Günümüzde ise ahşap malzemeler ile ilgili; yeterli bilgiye sahip olunmaması, toplumdaki yanlış algılar, tanıtım eksikliği, üretim aşamasında sektördeki sorunlar gibi faktörlerden dolayı ahşap malzemelerin yeteri kadar tercih edilmemesi büyük bir eksikliktir.

Tasarım firmaları ise tasarladığı ürünlerde malzeme tercihinde bulunabilecek işletmelerdir. Tasarım firmalarının tasarladığı bir üründe malzeme tercihindeki yaklaşımları önemlidir. Tasarımcının, tercih ettiği malzemenin bütün özelliklerini bilmesi ve tasarımını gerçekleştirdiği üründeki bütün gereksinimlerini karşılayacak potansiyele sahip olması gerekmektedir. Bu sebeple; tasarım alanında faaliyet gösteren iç mimarlık firmalarının ahşap malzemeleri tercih etmesi için ahşap malzemeler hakkındaki bilgileri ve kendilerinin ya da müşterilerinin talep durumları önem arz etmektedir. Bu çalışmanın amacı; iç mimarlık firmalarının ahşap malzeme ile ilgili görüşlerini ve ahşap malzeme kullanma eğilimlerini belirlemektir.

\section{Materyal ve Metot}

Türkiye genelini temsil eden İstanbul, Ankara ve İzmir illerindeki Ticaret odaları veya ticaret ve sanayi odalarında "Mesleki, Bilimsel ve Teknik Faaliyetler" grubunda "74.10.01" NACE kodu, "İç mimarların faaliyetleri (iç dekorasyon dahil)" adıyla faaliyet gösteren iç mimarlık firmalarından seçilmiş İstanbul'da 198, Ankara'da 54 ve İzmir'de 20 olmak üzere toplamda 272 adet işletmeye anket uygulayarak araştırma gerçekleştirilmiş̧tir.

İç mimarlık firmaları üzerine bir araştırma yapılması amacıyla iç mimarlık firmalarının yöneticilerine anket tekniği uygulanmıştır. $\mathrm{Bu}$ çalışma tarama modeline göre yürütüldüğünden, araştırma sorularının hazırlanması uygun görülmüştür. Araştırmanın amacına uygun olarak şu sorulara cevap aranmıştır: Katılımcıların işletmelerinin ahşap malzeme ile ilişkisine yönelik görüşleri nasıldır? Katılımcıların işletmelerinin ahşap malzeme kullanma eğilimleri ne düzeydedir? Anket tekniği ile katılımcılar tarafından soruların cevaplandırılması üzerine elde edilen veriler analiz edilmiştir. $\mathrm{Bu}$ araştırmada, araştırma modellerinden biri olan tarama modeli seçilmiştir ve bu tür araştırmalarda asıl amaç incelenen durumu etraflıca tanımlamak ve açıklamaktır. Bu araştırmalarda incelenen olayın özellikleri ve şartları bozulmadan inceleme yapılmaktadır. Buna uygun olarak, araştırma kapsamında, anket sorularına verilen cevapları incelemek için yüzde-frekans analizi kullanmış ve bu sayede katılımcıların görüşleri betimsel bir yaklaşım ile ortaya koyularak değerlendirmelerde bulunulmuştur. 


\section{$2.1 \quad$ Evren ve örneklem}

Çalışma kapsamında evren, Türkiye'deki ticaret odaları veya ticaret ve sanayi odalarında "Mesleki, Bilimsel ve Teknik Faaliyetler" grubunda "74.10.01" NACE kodu ve "İç mimarların faaliyetleri (iç dekorasyon dahil)" adıyla faaliyet gösteren iç mimarlık firmaları olarak ele alınmıştır. Türkiye'deki bütün illerdeki ticaret odaları veya ticaret ve sanayi odalarının resmi internet sitesindeki verilerden ya da tek tek aranarak iç mimarlık firmalarının sayısı bulunmuştur. Yapılan araştırmalar neticesinde, iç mimarlık firmalarının sayısı yani evren 2087 olarak elde edilmiştir. Evreni ilk 3 şehir sırasıyla, İstanbul $(\% 68,18)$, Ankara $(\% 11,36)$ ve İzmir $(\% 3,93)$ temsil etmektedir. Bu ilk 3 şehir, toplam evrenin \% 83,47'sini oluşturmuş ve Türkiye' yi temsil edebileceği düşünülmüştür. İstanbul, Ankara ve İzmir illerinde firma toplam sayısı ve yüzdesi Çizelge 1'de verilmiştir.

Çizelge 1. İstanbul, Ankara ve İzmir illerinde firma toplam sayısı ve yüzdesi

\begin{tabular}{|c|c|c|}
\hline ILLER & FIRMA SAYISI & EVREN YÜZDESI \\
\hline İSTANBUL & 1423 & 68,18 \\
\hline ANKARA & 237 & 11,36 \\
\hline İZMIR & 82 & 3,93 \\
\hline TOPLAM & $\mathbf{1 7 4 2}$ & $\mathbf{8 3 , 4 7}$ \\
\hline
\end{tabular}

\section{2 Örneklemin belirlenmesi}

Anket uygulanacak örneklem büyüklügünün belirlenmesinde aşağıdaki formül kullanılmıştır (Karasar, 1991).

$$
\mathrm{n}=\frac{\mathrm{Z}^{2} \times \mathrm{N} \times \mathrm{P} \times \mathrm{Q}}{\mathrm{N} \times \mathrm{D}^{2}+\mathrm{Z}^{2} \times \mathrm{P} \times \mathrm{Q}}
$$

Burada; n: Örnek büyüklüğ̈̈, N: Ana kütle büyüklüğü, Z: Güven katsayısı (\%95'lik güven için 1.96 alınmaktadır.), P: Ölçülen özelliğin ana kütlede bulunma olasılığı (\% 80 alınmıştır.), Q: 1-P (Ölçülen özelliğin ana kütlede bulunmama olasılı̆̆ı), D: Kabul edilen örnekleme hatası (\% 5 olarak öngörülmüştür.)

İstanbul, Ankara ve İzmir illerinde bulunan firmaların sayısı araştırma evrenini oluşturan toplam firmaların sayısına yüzdeleri hesaplanarak Çizelge 2'de verilmiştir.

Çizelge 2. Araştırma evrenine göre ilk 3 ilin yüzdesi

\begin{tabular}{|c|c|c|c|}
\hline ILLER & SAYI & YÜZDE & \multirow{2}{*}{ ARAŞTIRMA EVRENI } \\
\hline İSTANBUL & 1423 & 81,70 & \multirow{2}{*}{$\mathbf{1 7 4 2}$} \\
\hline ANKARA & 237 & 13,60 & \\
\hline İZMİR & 82 & 4,70 & \\
\hline
\end{tabular}

Yukarıdaki ilgili formül ve yüzdelere göre yapılan hesaplamalar sonrasında, anket uygulaması yapılacak örneklem büyüklügü ve illere göre dağılımı Çizelge 3'te verilmiştir. Bu çizelgeye göre; İstanbul Anket Sayısı $\geq 177$, Ankara Anket Sayısı $\geq 29$ ve İzmir Anket Sayısı $\geq 10$ olmalıdır. Örneklem büyüklüğü simgeleyen $n$ değeri 216 olarak bulunmuş ve toplam 272 firmaya anket uygulaması yapılarak ana kütle temsil edilmiştir.

Çizelge 3. İllere göre ve toplam örneklem dağılımı

\begin{tabular}{|c|c|c|}
\hline İLLER & ÖRNEKLEM BÜYÜKLÜĞÜ & \multirow{2}{*}{ TOPLAM ÖRNEKLEM BÜYÜKLÜĞÜ } \\
\hline ISTANBUL & 177 & \multirow{2}{*}{216} \\
\hline ANKARA & 29 \\
\hline İZMİR & 10 & \\
\hline
\end{tabular}




\subsection{Anket sorularının belirlenmesi ve yapısı}

Araştırma kapsamında veri toplama yöntemi olarak anket tekniği kullanılmıştır. Anket sorularının oluşturulmasında akademik araştırmalar, bazı kurumların veri tabanları ile akademik ve sektörel olarak uzman bilgi birikiminden yararlanılmıştır. Anket formu 4 bölümden oluşturulmuştur. Birinci bölümde, anketi yanıtlayana ait bilgiler istenirken, ikinci bölümde işletmeye ait genel bilgiler, üçüncü bölümde, İşletmenin ahşap malzeme ile ilişkisi ve dördüncü bölümde işletmenin ahşap malzeme kullanımı yer almıştır.

\subsection{Katılımcıların seçilmesi}

Anket uygulaması gerçekleştirilecek İstanbul, Ankara ve İzmir illerinde faaliyet gösteren iç mimarlık firmalarının belirlenmesinde tesadüfi örnekleme yöntemi kullanılarak rastgele seçim yapılmıştır.

\subsection{Güvenirlik analizi}

İç mimarlık firmalarına yönelik yapılan araştırmada toplanan veriler üzerinde yapılan "güvenirlik analizi” sonuçları aşağıda Çizelge 4'te sunulmuştur.

Çizelge 4. Araştırmada kullanılan anketlere ait alfa güvenirlik katsayıları

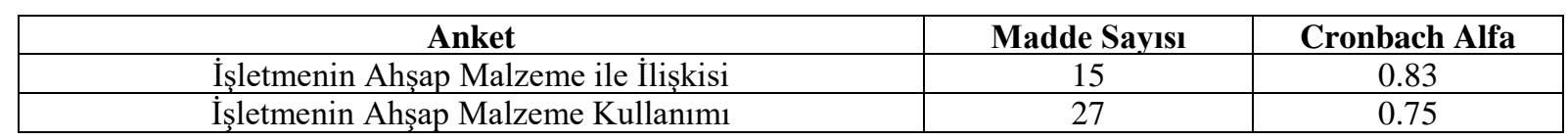

Çizelge incelendiğinde, anket formları için hesaplanan alfa katsayılarının 0,75 ve 0,83 olduğu anlaşılmıştır. Alfa katsayısı 0 ile 1 arasında değerler almaktadır. 0,70 ve üzerindeki alfa katsayıları güvenirlik için yeterli görülmektedir (Tavşancıl, 2005). Bu araştırmada elde edilen katsayılar anket formlarının iç tutarlılığa bağlı güvenirliğinin yeterli düzeyde olduğunu işaret etmiştir.

\subsection{Verilerin analizi}

Elde edilen verilerin değerlendirilmesinde Microsoft Office Excel ve SPSS programları kullanılmıştır. Microsoft Office Excel programında sorgulama, geliştirme ve düzenleme gibi işlemler yapılırken, SPSS programında ise güvenilirlik testleri, ilişki analizleri gibi uygulamalar gerçekleştirilmiştir. Araştırma kapsamında, katılımcıların anket formuna vermiş olduğu cevapların dağılımını incelemek için yüzde-frekans analizi uygulanmıştır. Veriler SPSS 25.0 istatistik paket programı kullanılarak analiz edilmiştir.

\section{Bulgular ve Tartışma}

\subsection{Katılımclara ait bilgiler}

Katılımcılara ait bilgileri elde etmek amacı ile anketi yanıtlayan kişinin unvanı ve eğitim düzeyi soruları yöneltilmiştir. Katılımcıların demografik özelliklerine göre dağılımı yüzde / frekans olarak Çizelge 5'te verilmiştir.

Çizelge 5. Katılımcıların demografik özelliklerine göre dağılımı

\begin{tabular}{cccc}
\hline & & Frekans & \% \\
\hline \multirow{2}{*}{ Anketi yanıtlayanın unvanı } & İşletme sahibi & 123 & 45.2 \\
& Profesyonel yönetici & 149 & 54.8 \\
\hline \multirow{2}{*}{ Anketi yanıtlayanın eğitim düzeyi } & Yükseköğretim & 232 & 85.3 \\
& Lisans üstü & 40 & 14.7 \\
\hline
\end{tabular}


Çizelge 5 incelendiğinde, araştırmaya dâhil edilen katılımcıların \%45,2'sinin işletme sahibi, \%54,8'inin ise profesyonel yönetici olduğu anlaşılmaktadır. Katılımcıların \%85,3'ü yükseköğretim, \%14,7'si lisansüstü eğitim mezunu olduğunu ifade etmiştir.

\section{2 İşletmeye ait bilgiler}

Anket uygulaması gerçekleştirilen işletmelere ait betimsel bilgileri öğrenmek için işletmelerin unvanı, bulunduğu şehir ve kuruluş yılı soruları yöneltilerek verilen cevaplar neticesinde yüzde / frekans değerleri analiz edilerek Çizelge 6'da verilmiştir.

Çizelge 6. Araştırmaya dâhil edilen işletmelere ait betimsel bilgiler

\begin{tabular}{cccc}
\hline & & Frekans & \% \\
\hline \multirow{2}{*}{ İşletmenin unvanı } & Şahıs şirketi & 69 & 25.4 \\
& Anonim şirket & 23 & 8.5 \\
& Limited şirket & 180 & 66.1 \\
\hline \multirow{2}{*}{ İşletmenin bulunduğu şehir } & Ankara & 54 & 19.8 \\
& İstanbul & 198 & 72.8 \\
\hline \multirow{2}{*}{ İşletmenin kuruluş yılı } & İzmir & 20 & 7.4 \\
& $1979-2012$ & 90 & 33.1 \\
& $2013-2016$ & 88 & 32.3 \\
\hline
\end{tabular}

Çizelge 6 incelendiğinde, araştırmaya dahil edilen işletmelerin büyük bir kısmının $\% 66,1$ oranla limited şirket, $\% 25,4$ 'ünün şahıs şirketi ve $\% 8,5$ 'inin anonim şirket olduğu anlaşılmaktadır. İşletmelerin büyük bir kısmı \%72,8 oranla İstanbul ilinde faaliyet gösterirken, \%19,8'inin Ankara'da ve \%7,4'ünün İzmir'de faaliyet gösterdiği belirlenmiştir. İşletmelerin kuruluş yıllarına baktığımızda, \%33,1'i 1979-2012 yılları arasında, \%32,3'ü 2013-2016 yılları arasında ve \%34,6'sı 2017-2020 yılları arasında kurulduğu saptanmıştır.

\section{3 İşletmenin ahşap malzeme ile ilişkisi}

$\mathrm{Bu}$ bölümde, işletmelerin ahşap malzeme ile ilişkisini belirlemek amacı ile anket formunda verilen ifadeleri 5'li Likert ölçeğine göre "Kesinlikle katılmiyorum", "Katılmiyorum", "Ne katıliyorum ne katılmiyorum", "Kat1lıyorum" ve "Kesinlikle katılıyorum" şeklinde değerlendirerek cevaplandırılması istenmiştir. Katılımcıların verdiği cevaplar neticesinde elde edilen verilerle yüzde, frekans, ortalama, ortanca ve tepe değerleri hesaplanarak ilgili başlıklar ve tablolar halinde verilmiştir. İşletmelerin ahşap malzemeler ile ilişkili görüşlerini incelemek için yapılan anket neticesinde katılımcıların verdiği cevaplar göre elde edilen değerler hesaplanarak Çizelge 7'de verilmiştir. Çizelge 7 incelendiğinde, "Firma ve çalışanları olarak ahşap malzemeler hakkında (özellikleri, çeşitleri, avantajları, korunması vb.) yeterli bilgiye sahibiz." ifadesine katılımcıların verdikleri cevapların "katıliyorum" düzeyinde $(\bar{x}=3,88, \quad \mathrm{OR}=4, \mathrm{TD}=4)$ olduğu görülmektedir. Kat1lımcılar işletmelerindeki çalışanların ahşap malzemeler hakkında yeterli bilgiye sahip olduğunu düşünmektedir. Ankette bulunan "Ahşap malzeme iç mekân mobilyalarında kullanım imkânları çok yüksek olan bir malzemedir." ifadesine katılımcıların verdikleri cevapların "katıliyorum" düzeyinde ( $\bar{x}=3,71, \mathrm{OR}=4, \mathrm{TD}=4)$ olduğu görülmektedir (Çizelge 7). Katılımcılar ahşap malzemenin iç mekan mobilyalarında kullanım imkanlarının oldukça yüksek olduğunu düşünmektedir. Anketin üçüncü maddesi olan "Ahşap malzeme diş mekân mobilyalarında kullanım imkânları çok yüksek olan bir malzemedir." ifadesine katılımcıların verdikleri cevapların "katılıyorum" düzeyinde $(\bar{x}=3,43, \mathrm{OR}=3, \mathrm{TD}=3)$ olduğu görülmektedir (Çizelge 7). Katılımcıların ahşap malzemenin dış mekân mobilyalarında kullanım imkânlarının oldukça yüksek olduğu görüşü ile ilgili kararsızlık yaşadığı gözlenmiştir. 
Çizelge 7. İşletmelerin ahşap malzeme ile ilişkili görüşlerinin incelenmesi

\begin{tabular}{|c|c|c|c|c|c|c|c|c|c|}
\hline İfadeler & & 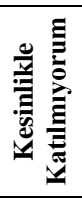 & E & 㤩 & E & 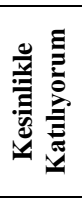 & Ort & OR & TD \\
\hline \multirow{2}{*}{$\begin{array}{l}\text { Firma ve çalışanları olarak ahşap malzemeler hakkında } \\
\text { (özellikleri. çeşitleri. avantajları. korunması vb.) yeterli } \\
\text { bilgiye sahibiz. }\end{array}$} & $\mathrm{f}$ & 3 & 10 & 60 & 142 & 57 & \multirow{2}{*}{3.88} & \multirow{2}{*}{4} & \multirow{2}{*}{4} \\
\hline & $\%$ & 1.1 & 3.7 & 22.1 & 52.2 & 21.0 & & & \\
\hline \multirow{2}{*}{$\begin{array}{l}\text { Ahşap malzeme iç mekan mobilyalarında kullanım } \\
\text { imkanları çok yüksek olan bir malzemedir. }\end{array}$} & $\mathrm{f}$ & 1 & 9 & 86 & 147 & 29 & \multirow{2}{*}{3.71} & \multirow{2}{*}{4} & \multirow{2}{*}{4} \\
\hline & $\%$ & 0.4 & 3.3 & 31.6 & 54.0 & 10.7 & & & \\
\hline \multirow{2}{*}{$\begin{array}{l}\text { Ahşap malzeme dış mekan mobilyalarında kullanım } \\
\text { imkanları çok yüksek olan bir malzemedir. }\end{array}$} & $\mathrm{f}$ & - & 40 & 114 & 80 & 38 & \multirow{2}{*}{3.43} & \multirow{2}{*}{3} & \multirow{2}{*}{3} \\
\hline & $\%$ & - & 14.7 & 41.9 & 29.4 & 14.0 & & & \\
\hline \multirow{2}{*}{$\begin{array}{l}\text { Ahşap malzeme iç mekan yapı malzemelerinde kullanım } \\
\text { imkanları çok yüksek olan bir malzemedir. }\end{array}$} & $\mathrm{f}$ & - & 33 & 112 & 98 & 29 & \multirow{2}{*}{3.45} & \multirow{2}{*}{3} & \multirow{2}{*}{3} \\
\hline & $\%$ & - & 12.1 & 41.2 & 36.0 & 10.7 & & & \\
\hline \multirow{2}{*}{$\begin{array}{l}\text { Ahşap malzeme dış mekan yapı malzemelerinde } \\
\text { kullanım imkanları çok yüksek olan bir malzemedir. }\end{array}$} & f & - & 43 & 92 & 106 & 31 & \multirow{2}{*}{3.46} & \multirow{2}{*}{4} & \multirow{2}{*}{4} \\
\hline & $\%$ & - & 15.8 & 33.8 & 39.0 & 11.4 & & & \\
\hline \multirow{2}{*}{$\begin{array}{l}\text { İç mekan uygulamalarımızda kullandığımız } \\
\text { mobilyalarda ahşap malzemeyi tercih ederiz. }\end{array}$} & $\mathrm{f}$ & 1 & 31 & 85 & 126 & 29 & \multirow{2}{*}{3.56} & \multirow{2}{*}{4} & \multirow{2}{*}{4} \\
\hline & $\%$ & 0.4 & 11.4 & 31.3 & 46.3 & 10.7 & & & \\
\hline \multirow{2}{*}{$\begin{array}{l}\text { Dış mekan uygulamalarımızda kullandığımız } \\
\text { mobilyalarda ahşap malzemeyi tercih ederiz. }\end{array}$} & $\mathrm{f}$ & 1 & 76 & 75 & 92 & 28 & \multirow{2}{*}{3.26} & \multirow{2}{*}{3} & \multirow{2}{*}{4} \\
\hline & $\%$ & 0.4 & 27.9 & 27.6 & 33.8 & 10.3 & & & \\
\hline \multirow{2}{*}{$\begin{array}{l}\text { İç mekan uygulamalarımızda kullandığımız yapı } \\
\text { malzemelerinde ahşap malzemeyi tercih ederiz. }\end{array}$} & $\mathrm{f}$ & - & 37 & 80 & 126 & 29 & \multirow{2}{*}{3.54} & \multirow{2}{*}{4} & \multirow{2}{*}{4} \\
\hline & $\%$ & - & 13.6 & 29.4 & 46.3 & 10.7 & & & \\
\hline \multirow{2}{*}{$\begin{array}{l}\text { Dış mekan uygulamalarımızda kullandığımız yapı } \\
\text { malzemelerinde ahşap malzemeyi tercih ederiz. }\end{array}$} & $\mathrm{f}$ & - & 54 & 91 & 105 & 22 & \multirow{2}{*}{3.35} & \multirow{2}{*}{3} & 4 \\
\hline & $\%$ & - & 19.9 & 33.5 & 38.6 & 8.1 & & & \\
\hline
\end{tabular}

Ort: Ortalama, OR: Ortanca, TD: Tepe değer, f: Frekans, \%: Yüzde

Anketin dördüncü maddesi olan "Ahşap malzeme iç mekan yapı malzemelerinde kullanım imkanları çok yüksek olan bir malzemedir." ifadesine katılımcıların verdikleri cevapların "katıllyorum" düzeyinde $(\bar{x}=3,45, \mathrm{OR}=3, \mathrm{TD}=3)$ olduğu görülmektedir (Çizelge 7). Katılımcıların ahşap malzemenin iç mekân yapı malzemelerinde kullanım imkânlarının oldukça yüksek olduğu görüşü ile ilgili kararsız bir tutum sergiledikleri gözlenmiştir.

Anketin beşinci maddesi olan "Ahşap malzeme dış mekân yapı malzemelerinde kullanım imkânları çok yüksek olan bir malzemedir." ifadesine katılımcıların verdikleri cevapların "katılıyorum" düzeyinde $(\bar{x}=3,46, \mathrm{OR}=4, \mathrm{TD}=4)$ olduğu görülmektedir (Çizelge 7). Katılımcıların ahşap malzemenin dış mekân yapı malzemelerinde kullanım imkânlarının oldukça yüksek olduğu görüşünü benimsediği söylenebilir.

Anketin altıncı maddesi olan "İç mekân uygulamalarımızda kullandığımız mobilyalarda ahşap malzemeyi tercih ederiz." ifadesine katılımcıların verdikleri cevapların "katılıyorum" düzeyinde $(\bar{x}=3,56, \mathrm{OR}=4, \mathrm{TD}=4)$ olduğu görülmektedir (Çizelge 7). Katılımcıların iç mekân uygulamaları için ahşap malzemeleri tercih etme eğilimlerinin yüksek olduğu anlaşılmaktadır.

Anketin yedinci maddesi olan "Dış mekân uygulamalarımızda kullandığımız mobilyalarda ahşap malzemeyi tercih ederiz." ifadesine katılımcıların verdikleri cevapların "Ne Katılıyorum Ne Katılmıyorum" düzeyinde $(\bar{x}=3,26, \mathrm{OR}=3, \mathrm{TD}=4)$ olduğu görülmektedir (Çizelge 7). Ortanca ve tepe değer dikkate alındığında katılımcıların dış mekân uygulamaları için ahşap malzemeleri tercih etme eğilimlerinin bulunduğu gözlenmiştir.

Anketin sekizinci maddesi olan "İç mekân uygulamalarımızda kullandığımız yapı malzemelerinde ahşap malzemeyi tercih ederiz." ifadesine katılımcıların verdikleri cevapların "kat1lyyorum" düzeyinde $(\bar{x}=3,54, \mathrm{OR}=4, \mathrm{TD}=4)$ olduğu görülmektedir (Çizelge 7). Katılımcıların iç mekân uygulamaları için ahşap malzemeleri tercih etme eğilimlerinin yüksek olduğu söylenebilir. 
Anketin dokuzuncu maddesi olan "Dış mekân uygulamalarımızda kullandığımız yapı malzemelerinde ahşap malzemeyi tercih ederiz." ifadesine katılımcıların verdikleri cevapların "Ne Katılıyorum Ne Katılmıyorum" düzeyinde $(\bar{x}=3,35, \mathrm{OR}=3, \mathrm{TD}=4)$ olduğu görülmektedir (Çizelge 7). Ortanca ve tepe değer dikkate alındığında ise katılımcıların dış mekân uygulamalarında ahşap yapı malzemelerini tercih etme eğilimlerinin bulunduğu gözlenmiştir.

İşletme müşterilerinin ahşap malzemeler ile ilişkili görüşlerini belirlemek amacıyla yapılan anket sonucunda katılımcıların verdiği cevaplara göre elde edilen değerler hesaplanarak Çizelge 8'de verilmiştir.

Çizelge 8. İşletme müşterilerinin ahşap malzemeler ile ilişkili görüşlerinin incelenmesi

\begin{tabular}{|c|c|c|c|c|c|c|c|c|c|}
\hline İfadeler & & 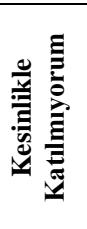 & 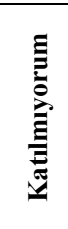 & 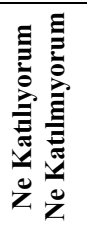 & E & 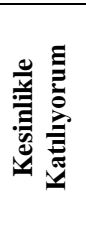 & Ort & OR & TD \\
\hline \multirow{2}{*}{$\begin{array}{l}\text { Müşterilerimiz iç mekan mobilyalarında ahşap } \\
\text { malzemeyi talep ediyor. }\end{array}$} & $\mathrm{f}$ & 1 & 41 & 93 & 113 & 24 & \multirow{2}{*}{3,43} & \multirow{2}{*}{4} & \multirow{2}{*}{4} \\
\hline & $\%$ & 0.4 & 15.1 & 34.2 & 41.5 & 8.8 & & & \\
\hline \multirow{2}{*}{$\begin{array}{l}\text { Müşterilerimiz dış mekan mobilyalarında ahşap } \\
\text { malzemeyi talep ediyor. }\end{array}$} & $\mathrm{f}$ & 1 & 45 & 89 & 116 & 21 & \multirow{2}{*}{3,41} & \multirow{2}{*}{4} & \multirow{2}{*}{4} \\
\hline & $\%$ & 0.4 & 16.5 & 32.7 & 42.6 & 7.7 & & & \\
\hline \multirow{2}{*}{$\begin{array}{l}\text { Müşterilerimiz iç mekan yapı malzemelerinde } \\
\text { ahşap malzemeyi talep ediyor. }\end{array}$} & $\mathrm{f}$ & - & 38 & 86 & 115 & 33 & \multirow{2}{*}{3,53} & \multirow{2}{*}{4} & \multirow{2}{*}{4} \\
\hline & $\%$ & - & 14.0 & 31.6 & 42.3 & 12.1 & & & \\
\hline \multirow{2}{*}{$\begin{array}{l}\text { Müşterilerimiz dış mekan yapı malzemelerinde } \\
\text { ahşap malzemeyi talep ediyor. }\end{array}$} & $\mathrm{f}$ & 1 & 44 & 92 & 103 & 32 & \multirow{2}{*}{3,44} & \multirow{2}{*}{3} & \multirow{2}{*}{4} \\
\hline & $\%$ & 0.4 & 16.2 & 33.8 & 37.9 & 11.8 & & & \\
\hline
\end{tabular}

Ort: Ortalama, OR: Ortanca, TD: Tepe değer, f: Frekans, \%: Yüzde

Anketin ilk maddesi olan "Müşterilerimiz iç mekân mobilyalarında ahşap malzemeyi talep ediyor." ifadesine katılımciların verdikleri cevapların "katılıyorum" düzeyinde $(\bar{x}=3,43$, $\mathrm{OR}=4, \mathrm{TD}=4$ ) olduğu görülmektedir. Müşterilerin iç mekân mobilyalılarında ahşap malzeme talep ettikleri görüşünde katılımcıların fikir birliği içinde oldukları söylenebilir.

Anketin ikinci maddesi olan "Müşterilerimiz dış mekân mobilyalarında ahşap malzemeyi talep ediyor." ifadesine katılımcıların verdikleri cevapların "katılıyorum" düzeyinde $(\bar{x}=3,41, \mathrm{OR}=4, \mathrm{TD}=4)$ olduğu görülmektedir (Çizelge 8). Müşterilerin dış mekân mobilyalılarında ahşap malzeme talep ettikleri ile ilgili katılımcıların fikir birliği içinde oldukları gözlenmiştir.

Anketin üçüncü maddesi olan "Müşterilerimiz iç mekân yap1 malzemelerinde ahşap malzemeyi talep ediyor." ifadesine katılımcıların verdikleri cevapların "katıllyorum" düzeyinde $(\bar{x}=3,53, \mathrm{OR}=4, \mathrm{TD}=4)$ olduğu görülmektedir (Çizelge 8). Müşterilerin iç mekânda ahşap yapı malzemelerini talep ettikleri ile ilgili katılımcıların fikir birliği içinde oldukları gözlenmiştir.

Anketin dördüncü maddesi olan "Müşterilerimiz diş mekân yapı malzemelerinde ahşap malzemeyi talep ediyor." ifadesine katılımcıların verdikleri cevapların "katıliyorum" düzeyinde $(\bar{x}=3,44, \quad \mathrm{OR}=3, \mathrm{TD}=4)$ olduğu görülmektedir (Çizelge 8). Katılımcıların müşterilerin diş mekânda ahşap yapı malzemelerini talep ettikleri görüşü ile ilgili olarak kararsız kaldıkları söylenebilir.

İşletmelerin ahşap malzeme ile ilgili yapılan seminer, konferans, fuar vb. yerlere davet alma ve katılım sağlama durumlarını incelemek için katılımcıların yapılan ankete verdiği cevaplar neticesinde elde edilen değerler hesaplanarak Çizelge 9'da verilmiştir. 
Çizelge 9. İşletmelerin ahşap malzeme ile ilgili etkinliklere davet alma ve katılım sağlama durumlarının incelenmesi

\begin{tabular}{|c|c|c|c|c|c|c|c|c|c|}
\hline İfadeler & & 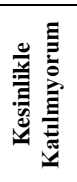 & 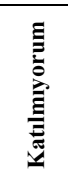 & 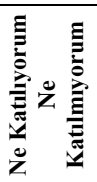 & E & 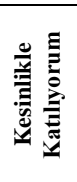 & Ort & OR & TD \\
\hline \multirow{2}{*}{$\begin{array}{l}\text { Ahşap malzeme ile ilgili yapılan seminer, konferans, fuar } \\
\text { vb. yerlere katılım için davet alırız. }\end{array}$} & $\mathrm{f}$ & 24 & 53 & 83 & 91 & 21 & \multirow{2}{*}{3.12} & \multirow{2}{*}{3} & \multirow{2}{*}{4} \\
\hline & $\%$ & 8.8 & 19.5 & 30.5 & 33.5 & 7.7 & & & \\
\hline $\begin{array}{l}\text { Ahşap malzeme ile ilgili yapılan seminer, konferans, fuar } \\
\text { vb. yerlere katılım sağlarız. }\end{array}$ & $\begin{array}{c}\mathrm{f} \\
\%\end{array}$ & $\begin{array}{l}20 \\
7.4\end{array}$ & $\begin{array}{c}38 \\
14.0\end{array}$ & $\begin{array}{c}87 \\
32.0\end{array}$ & $\begin{array}{c}108 \\
39.7\end{array}$ & $\begin{array}{l}19 \\
7.0\end{array}$ & 3.25 & 3 & 4 \\
\hline
\end{tabular}

Ort: Ortalama, OR: Ortanca, TD: Tepe değer, f: Frekans, \%: Yüzde

Anketin ilk maddesi olan "Ahşap malzeme ile ilgili yapılan seminer, konferans, fuar vb. yerlere katılım için davet alıyoruz" ifadesine katılımcıların verdikleri cevapların " $\mathrm{Ne}$ katılıyorum ne katılmiyorum" düzeyinde $(\bar{x}=3,12, \mathrm{OR}=3, \mathrm{TD}=4)$ olduğu görülmektedir (Çizelge 9). Katılımcıların ahşap malzeme ile ilgili yapılan etkinlikler için yeteri kadar davet almadıkları söylenebilir. Anketin ikinci maddesi olan "Ahşap malzeme ile ilgili yapılan seminer, konferans, fuar vb. yerlere katılım sağlarız" ifadesine katılımcıların verdikleri cevapların "Ne katıliyorum ne katılmiyorum" düzeyinde $(\bar{x}=3,25, \mathrm{OR}=3, \mathrm{TD}=4)$ olduğu görülmektedir (Çizelge 9). Katılımcıların ahşap malzeme ile ilgili yapılan etkinliklere yeteri kadar katılım sağlamadıklarını düşündükleri söylenebilir.

\section{4 İşletmenin ahşap malzeme kullanımı}

$\mathrm{Bu}$ kısımda, işletmelerin ahşap malzeme kullanımını incelemek amacıyla anket formunda verilen malzeme türünü 5'li Likert ölçeğine göre "Hiç Yok", "Az", "Orta", "Fazla" ve "Çok Fazla" şeklinde değerlendirerek cevaplandırılması istenmiştir. Katılımcıların verdiği cevaplara göre elde edilen verilerle yüzde, frekans, ortalama, ortanca ve tepe değerleri hesaplanarak ilgili başlıklar ve çizelge halinde verilmiştir (Çizelge 10).

Çizelge 10. İşletmelerin iç mekânlardaki mobilyalarda kullandığı ahşap malzeme türlerinin incelenmesi

\begin{tabular}{|c|c|c|c|c|c|c|c|c|c|}
\hline \multicolumn{2}{|c|}{$\begin{array}{l}\text { İc mekânlardaki mobilyalarda kullandığınız } \\
\text { ahşap malzeme türünü derecelendiriniz. }\end{array}$} & \multirow{3}{*}{ 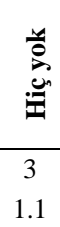 } & \multirow{3}{*}{$\begin{array}{l}\frac{N}{4} \\
18 \\
6.6\end{array}$} & \multirow{3}{*}{$\begin{array}{c}\frac{\pi}{5} \\
72 \\
26.5\end{array}$} & \multirow{3}{*}{ 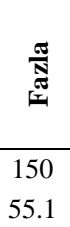 } & \multirow{3}{*}{ 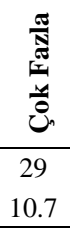 } & \multirow{3}{*}{$\begin{array}{c}\text { Ort } \\
3.68\end{array}$} & \multirow{3}{*}{$\begin{array}{c}\text { OR } \\
4\end{array}$} & \multirow{3}{*}{$\begin{array}{r}\text { TD } \\
4\end{array}$} \\
\hline \multirow{2}{*}{ Masif Ahşap Malzeme } & $\mathrm{f}$ & & & & & & & & \\
\hline & $\%$ & & & & & & & & \\
\hline \multirow{2}{*}{ Lamine Ahşap Malzeme } & $\mathrm{f}$ & - & 59 & 70 & 128 & 15 & \multirow{2}{*}{3.36} & \multirow{2}{*}{4} & \multirow{2}{*}{4} \\
\hline & $\%$ & - & 21.7 & 25.7 & 47.1 & 5.5 & & & \\
\hline \multirow{2}{*}{ Kaplama } & $\mathrm{f}$ & - & 50 & 107 & 99 & 16 & \multirow{2}{*}{3.30} & \multirow{2}{*}{3} & \multirow{2}{*}{3} \\
\hline & $\%$ & - & 18.4 & 39.3 & 36.4 & 5.9 & & & \\
\hline \multirow{2}{*}{$\mathrm{MDF}$} & $\mathrm{f}$ & - & 59 & 127 & 75 & 11 & \multirow{2}{*}{3.14} & \multirow{2}{*}{3} & \multirow{2}{*}{3} \\
\hline & $\%$ & - & 21.7 & 46.7 & 27.6 & 4.0 & & & \\
\hline \multirow{2}{*}{ Yonga levha (Sunta) } & $\mathrm{f}$ & 1 & 105 & 100 & 55 & 11 & \multirow{2}{*}{2.89} & \multirow{2}{*}{3} & \multirow{2}{*}{2} \\
\hline & $\%$ & 0.4 & 38.6 & 36.8 & 20.2 & 4.0 & & & \\
\hline \multirow{2}{*}{ MDF Lam } & $\mathrm{f}$ & 3 & 69 & 68 & 115 & 17 & \multirow{2}{*}{3.27} & \multirow{2}{*}{3} & \multirow{2}{*}{4} \\
\hline & $\%$ & 1.1 & 25.4 & 25.0 & 42.3 & 6.3 & & & \\
\hline \multirow{2}{*}{ Sunta Lam } & $f$ & 5 & 56 & 68 & 133 & 10 & \multirow{2}{*}{3.32} & \multirow{2}{*}{4} & \multirow{2}{*}{4} \\
\hline & $\%$ & 1.8 & 20.6 & 25.0 & 48.9 & 3.7 & & & \\
\hline \multirow{2}{*}{ Kontrplak } & $\mathrm{f}$ & 3 & 66 & 96 & 100 & 7 & 15 & 3 & 4 \\
\hline & $\%$ & 1.1 & 24.3 & 35.3 & 36.8 & 2.6 & 3.15 & 3 & 4 \\
\hline Kontratabla & $\mathrm{f}$ & 2 & 92 & 80 & 93 & 5 & 303 & 3 & 4 \\
\hline Muilitialavia & $\%$ & 0.7 & 33.8 & 29.4 & 34.2 & 1.8 & & 3 & 4 \\
\hline
\end{tabular}

Ort: Ortalama, OR: Ortanca, TD: Tepe değer, f: Frekans, \%: Yüzde 
İşletmelerin iç mekânlardaki mobilyalarda kullandığı ahşap malzeme türlerini belirlemek için katılımcıların yapılan anketlere verdiği cevaplar neticesinde elde edilen değerler hesaplanarak Çizelge 10'da verilmiştir. Çizelge 10 incelendiğinde, iç mekânlardaki mobilyalarda kullanılan ahşap malzemeler ile ilgili, işletmelerin büyük bir oranı masif ahşap $(\% 55,1)$, lamine ahşap $(\% 47,1)$, MDF lam $(\% 42,3)$, sunta lam $(\% 48,9)$ malzemelerini fazla kullandığını ifade etmiştir. Kaplama malzemesi işletmeler tarafından daha çok orta $(\% 39,3)$ ve fazla $(\% 36,4)$ düzeyde kullanılmaktadır. MDF malzemesi ise işletmeler tarafından daha çok orta $(\% 46,7)$ düzeyde kullanmaktadır. İşletmelerin büyük bir oranı yonga levha (sunta), kontrplak ve kontratabla malzemelerini ise az, orta ve fazla düzeyde kullandığını belirtmiştir.

İşletmelerin diş mekânlardaki mobilyalarda kullandığı ahşap malzeme türlerini belirlemek amacıyla yapılan anket uygulamasında katılımcıların verdiği cevaplara göre elde edilerek hesaplanan değerler Çizelge 11'de verilmiştir. Çizelge 11 incelendiğinde, diş mekânlardaki mobilyalarda kullanılan ahşap malzemeler ile ilgili, işletmelerin büyük bir oranı masif ahşap malzemeyi orta $(\% 27,9)$ ve fazla $(\% 41,5)$ düzeyde kullandığını ifade etmiştir. İşletmelerin büyük bir oranı lamine ahşap malzeme, kaplama, MDF, yonga levha, MDF lam, sunta lam, kontrplak, kontratabla malzemelerini dış mekânlardaki mobilyalarda az, orta ve fazla düzeyde kullandığını belirtmiştir.

Çizelge 11. İşletmelerin diş mekânlardaki mobilyalarda kullandığı ahşap malzeme türlerinin incelenmesi

\begin{tabular}{|c|c|c|c|c|c|c|c|c|c|}
\hline $\begin{array}{l}\text { Dış mekânlardaki mobilyalard } \\
\text { malzeme türünü dere }\end{array}$ & Iz ahşap & 告 & 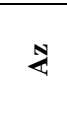 & $\ddot{\sigma}$ & 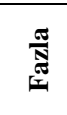 & 光 & Ort & OR & TD \\
\hline \multirow{2}{*}{ Masif Ahşap Malzeme } & f & 5 & 41 & 76 & 113 & 37 & \multirow{2}{*}{3.50} & \multirow{2}{*}{4} & \multirow{2}{*}{4} \\
\hline & $\%$ & 1.8 & 15.1 & 27.9 & 41.5 & 13.6 & & & \\
\hline \multirow{2}{*}{ Lamine Ahşap Malzeme } & $\mathrm{f}$ & 4 & 66 & 82 & 85 & 35 & \multirow{2}{*}{3.30} & \multirow{2}{*}{3} & \multirow{2}{*}{4} \\
\hline & $\%$ & 1.5 & 24.3 & 30.1 & 31.3 & 12.9 & & & \\
\hline \multirow{2}{*}{ Kaplama } & $\mathrm{f}$ & 4 & 106 & 84 & 58 & 20 & \multirow{2}{*}{2.94} & \multirow{2}{*}{3} & \multirow{2}{*}{2} \\
\hline & $\%$ & 1.5 & 39.0 & 30.9 & 21.3 & 7.4 & & & \\
\hline \multirow{2}{*}{ MDF } & f & 2 & 67 & 93 & 83 & 27 & \multirow{2}{*}{3.24} & \multirow{2}{*}{3} & \multirow{2}{*}{3} \\
\hline & $\%$ & 0.7 & 24.6 & 34.2 & 30.5 & 9.9 & & & \\
\hline \multirow{2}{*}{ Yonga levha (Sunta) } & $\mathrm{f}$ & 1 & 78 & 94 & 80 & 19 & \multirow{2}{*}{3.14} & \multirow{2}{*}{3} & \multirow{2}{*}{3} \\
\hline & $\%$ & 0.4 & 28.7 & 34.6 & 29.4 & 7.0 & & & \\
\hline \multirow{2}{*}{ MDF Lam } & f & 1 & 73 & 80 & 91 & 27 & \multirow{2}{*}{3.26} & \multirow{2}{*}{3} & \multirow{2}{*}{4} \\
\hline & $\%$ & 0.4 & 26.8 & 29.4 & 33.5 & 9.9 & & & \\
\hline \multirow{2}{*}{ Sunta Lam } & $\mathrm{f}$ & 1 & 83 & 69 & 105 & 14 & \multirow{2}{*}{3.18} & \multirow{2}{*}{3} & \multirow{2}{*}{4} \\
\hline & $\%$ & 0.4 & 30.5 & 25.4 & 38.6 & 5.1 & & & \\
\hline \multirow{2}{*}{ Kontrplak } & $\mathrm{f}$ & 1 & 106 & 79 & 80 & 6 & \multirow{2}{*}{2.94} & \multirow{2}{*}{3} & \multirow{2}{*}{2} \\
\hline & $\%$ & 0.4 & 39.0 & 29.0 & 29.4 & 2.2 & & & \\
\hline \multirow{2}{*}{ Kontratabla } & $\mathrm{f}$ & 1 & 100 & 80 & 82 & 9 & \multirow{2}{*}{2.99} & \multirow{2}{*}{3} & 2 \\
\hline & $\%$ & 0.4 & 36.8 & 29.4 & 30.1 & 3.3 & & & 2 \\
\hline
\end{tabular}

Ort: Ortalama, OR: Ortanca, TD: Tepe değer, f: Frekans, \%: Yüzde

İşletmelerin iç mekânlardaki yapı malzemelerinde kullandığı ahşap malzeme türleri belirlenmeye çalışılmış ve katılımcıların yapılan anketlere verdiği cevaplar neticesinde elde edilen değerler hesaplanarak Çizelge 12'de verilmiştir. Çizelge 12 incelendiğinde, iç mekândaki yapı malzemelerinde kullanılan ahşap malzemeler ile ilgili, işletmelerin büyük bir oranı masif ahşap malzemeyi orta $(\% 29,4)$ ve fazla $(\% 39,7)$ düzeyde kullandığını ifade etmiştir. Lamine ahşap malzeme, suntalam, kontrplak ve kontratabla malzemeler işletmeler tarafından daha çok orta ve fazla düzeyde kullanılmaktadır. Kaplama, MDF, Yonga levha (Sunta) ve MDFlam malzemelerinin ise işletmeler tarafından daha çok orta düzeyde kullanıldığı tespit edilmiştir. 
Çizelge 12. İşletmelerin iç mekânlardaki yapı malzemelerinde kullandığı ahşap malzeme türlerinin incelenmesi

\begin{tabular}{|c|c|c|c|c|c|c|c|c|c|}
\hline \multicolumn{2}{|c|}{$\begin{array}{c}\text { İç mekanlardaki yapı malzemelerinde } \\
\text { kullandığınız ahşap malzeme türünü } \\
\text { derecelendiriniz. }\end{array}$} & \multirow{2}{*}{ 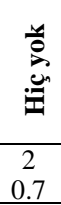 } & \multirow{2}{*}{$\begin{array}{c}4 \\
52 \\
19.1 \\
\end{array}$} & \multirow{2}{*}{$\begin{array}{c}\stackrel{5}{0} \\
80 \\
29.4\end{array}$} & \multirow{2}{*}{ 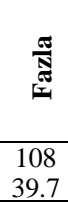 } & \multirow{2}{*}{ 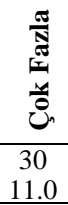 } & \multirow{2}{*}{$\begin{array}{l}\text { Ort } \\
3.41\end{array}$} & \multirow{2}{*}{$\begin{array}{c}\text { OR } \\
4 \\
\end{array}$} & \multirow{2}{*}{$\begin{array}{r}\text { TD } \\
4 \\
\end{array}$} \\
\hline Masif Ahşap Malzeme & $\begin{array}{c}\mathrm{f} \\
\%\end{array}$ & & & & & & & & \\
\hline Lamine Ahşap Malzeme & $\begin{array}{c}\mathrm{f} \\
\%\end{array}$ & $\begin{array}{c}4 \\
1.5 \\
\end{array}$ & $\begin{array}{c}73 \\
26.8 \\
\end{array}$ & $\begin{array}{c}88 \\
32.4 \\
\end{array}$ & $\begin{array}{c}93 \\
34.2\end{array}$ & $\begin{array}{r}14 \\
5.1 \\
\end{array}$ & 3.15 & 3 & 4 \\
\hline Kaplama & $\begin{array}{l}\mathrm{f} \\
\%\end{array}$ & $\begin{array}{c}6 \\
2.2\end{array}$ & $\begin{array}{c}57 \\
21.0\end{array}$ & $\begin{array}{r}127 \\
46.7\end{array}$ & $\begin{array}{c}66 \\
24.3\end{array}$ & $\begin{array}{r}16 \\
5.9\end{array}$ & 3.11 & 3 & 3 \\
\hline MDF & $\begin{array}{c}\mathrm{f} \\
\% \\
\end{array}$ & $\begin{array}{c}1 \\
0.4\end{array}$ & $\begin{array}{c}50 \\
18.4 \\
\end{array}$ & $\begin{array}{r}118 \\
43.4 \\
\end{array}$ & $\begin{array}{c}81 \\
29.8 \\
\end{array}$ & $\begin{array}{r}22 \\
8.1 \\
\end{array}$ & 3.27 & 3 & 3 \\
\hline Yonga levha (Sunta) & $\begin{array}{l}\mathrm{f} \\
\%\end{array}$ & $\begin{array}{c}3 \\
1.1 \\
\end{array}$ & $\begin{array}{c}72 \\
26.5 \\
\end{array}$ & $\begin{array}{r}110 \\
40.4\end{array}$ & $\begin{array}{c}66 \\
24.3 \\
\end{array}$ & $\begin{array}{l}21 \\
7.7 \\
\end{array}$ & 3.11 & 3 & 3 \\
\hline MDF Lam & $\begin{array}{l}\mathrm{f} \\
\% \\
\end{array}$ & $\begin{array}{c}1 \\
0.4 \\
\end{array}$ & $\begin{array}{c}45 \\
16.5 \\
\end{array}$ & $\begin{array}{r}112 \\
41.2 \\
\end{array}$ & $\begin{array}{c}97 \\
35.7 \\
\end{array}$ & $\begin{array}{l}17 \\
6.3 \\
\end{array}$ & 3.31 & 3 & 3 \\
\hline Sunta Lam & $\begin{array}{l}\mathrm{f} \\
\%\end{array}$ & $\begin{array}{c}1 \\
0.4 \\
\end{array}$ & $\begin{array}{c}65 \\
23.9 \\
\end{array}$ & $\begin{array}{r}104 \\
38.2 \\
\end{array}$ & $\begin{array}{c}94 \\
34.6 \\
\end{array}$ & $\begin{array}{c}8 \\
2.9 \\
\end{array}$ & 3.16 & 3 & 3 \\
\hline Kontrplak & $\begin{array}{l}\mathrm{f} \\
\%\end{array}$ & $\begin{array}{c}1 \\
0.4\end{array}$ & $\begin{array}{c}72 \\
26.5\end{array}$ & $\begin{array}{c}96 \\
35.3\end{array}$ & $\begin{array}{c}96 \\
35.3\end{array}$ & $\begin{array}{c}7 \\
2.6\end{array}$ & 3.13 & 3 & 3 \\
\hline Kontratabla & $\begin{array}{l}\mathrm{f} \\
\%\end{array}$ & $\begin{array}{c}3 \\
1.1 \\
\end{array}$ & $\begin{array}{c}66 \\
24.3 \\
\end{array}$ & $\begin{array}{c}98 \\
36.0 \\
\end{array}$ & $\begin{array}{c}86 \\
31.6 \\
\end{array}$ & $\begin{array}{l}19 \\
7.0 \\
\end{array}$ & 3.19 & 3 & 3 \\
\hline
\end{tabular}

Ort: Ortalama, OR: Ortanca, TD: Tepe değer, f: Frekans, \%: Yüzde

Anket uygulaması sonucunda, işletmelerin dış mekânlardaki yapı malzemelerinde kullandığ 1 ahşap malzeme türlerini belirlemek için katılımcıların verdiği cevaplara göre elde edilen değerler hesaplanarak Çizelge 13'te verilmiştir. Çizelge 13 incelendiğinde, diş mekândaki yapı malzemelerinde kullanılan ahşap malzemeler ile ilgili, işletmelerin büyük bir oranı masif ahşap (\%36), lamine ahşap $(\% 36,8)$, yonga levha $(\% 35,3)$, MDFlam $(\% 37,1)$, suntalam $(\% 38,2)$, kontrplak $(\% 34,9)$ ve kontratabla $(\% 34,2)$ malzemelerinin fazla düzeyde kullandığını ifade etmiştir. Kaplama malzeme daha çok az düzeyde $(\% 34,2)$, MDF ise daha çok orta düzeyde $(\% 32,4)$ işletmeler tarafından dış mekândaki yapılar için kullanılmaktadır.

Çizelge 13. İşletmelerin dış mekânlardaki yapı malzemelerinde kullandığı ahşap malzeme türlerinin incelenmesi

\begin{tabular}{|c|c|c|c|c|c|c|c|c|c|}
\hline \multicolumn{2}{|c|}{$\begin{array}{l}\text { Dış mekânlardaki yapı malzemelerinde } \\
\text { kullandığınız ahşap malzeme türünü } \\
\text { derecelendiriniz. }\end{array}$} & \multirow{3}{*}{ 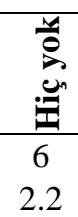 } & \multirow{3}{*}{$\begin{array}{c}\frac{N}{4} \\
57 \\
21.0\end{array}$} & \multirow{3}{*}{$\begin{array}{c}\stackrel{5}{0} \\
59 \\
21.7\end{array}$} & \multirow{3}{*}{ 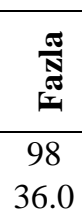 } & \multirow{3}{*}{ 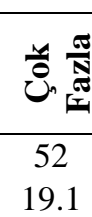 } & \multirow{3}{*}{$\begin{array}{l}\text { Ort } \\
3.49\end{array}$} & \multirow{3}{*}{$\begin{array}{c}\text { OR } \\
4\end{array}$} & \multirow{3}{*}{$\begin{array}{r}\text { TD } \\
4\end{array}$} \\
\hline & $\mathrm{f}$ & & & & & & & & \\
\hline Masif Ahşap Malzeme & $\%$ & & & & & & & & \\
\hline \multirow{2}{*}{ Lamine Ahşap Malzeme } & $\mathrm{f}$ & 2 & 64 & 76 & 100 & 30 & \multirow{2}{*}{3.34} & \multirow{2}{*}{3} & \multirow{2}{*}{4} \\
\hline & $\%$ & 0.7 & 23.5 & 27.9 & 36.8 & 11.0 & & & \\
\hline \multirow{2}{*}{ Kaplama } & $\mathrm{f}$ & 5 & 93 & 69 & 86 & 19 & \multirow{2}{*}{3.08} & \multirow{2}{*}{3} & \multirow{2}{*}{2} \\
\hline & $\%$ & 1.8 & 34.2 & 25.4 & 31.6 & 7.0 & & & \\
\hline \multirow[b]{2}{*}{ MDF } & $\mathrm{f}$ & 7 & 67 & 88 & 82 & 28 & \multirow{2}{*}{3.21} & \multirow{2}{*}{3} & \multirow{2}{*}{3} \\
\hline & $\%$ & 2.6 & 24.6 & 32.4 & 30.1 & 10.3 & & & \\
\hline \multirow{2}{*}{ Yonga levha (Sunta) } & $\mathrm{f}$ & 5 & 75 & 80 & 96 & 16 & \multirow[b]{2}{*}{3.16} & \multirow{2}{*}{3} & \multirow[b]{2}{*}{4} \\
\hline & $\%$ & 1.8 & 27.6 & 29.4 & 35.3 & 5.9 & & & \\
\hline \multirow{2}{*}{ MDF Lam } & $\mathrm{f}$ & 3 & 57 & 87 & 101 & 24 & \multirow[b]{2}{*}{3.32} & \multirow{2}{*}{3} & \multirow[b]{2}{*}{4} \\
\hline & $\%$ & 1.1 & 21.0 & 32.0 & 37.1 & 8.8 & & & \\
\hline \multirow{2}{*}{ Sunta Lam } & $\mathrm{f}$ & 4 & 65 & 70 & 104 & 29 & \multirow{2}{*}{3.33} & \multirow{2}{*}{3} & \multirow{2}{*}{4} \\
\hline & $\%$ & 1.5 & 23.9 & 25.7 & 38.2 & 10.7 & & & \\
\hline \multirow{2}{*}{ Kontrplak } & $\mathrm{f}$ & 7 & 78 & 74 & 95 & 18 & \multirow{2}{*}{3.14} & & \\
\hline & $\%$ & 2.6 & 28.7 & 27.2 & 34.9 & 6.6 & & 3 & 4 \\
\hline Vo & $\mathrm{f}$ & 2 & 90 & 82 & 93 & 5 & 200 & 2 & 4 \\
\hline Kontratabla & $\%$ & 0.7 & 33.1 & 30.1 & 34.2 & 1.8 & 3.03 & 3 & 4 \\
\hline
\end{tabular}

Ort: Ortalama, OR: Ortanca, TD: Tepe değer, f: Frekans, \%: Yüzde 
İşletmelerin ahşap malzeme kullanmayı tercih etme nedenlerini incelemek için yapılan anket uygulaması sonucunda katılımcıların verdiği cevaplara göre elde edilen değerler hesaplanarak Çizelge 14'te verilmiştir. Çizelge 14 incelendiğinde, ahşap malzemelerin; kolay temin edilmesi $(\bar{x}=3,56, \mathrm{OR}=4, \mathrm{TD}=4)$, doğal olmasi $(\bar{x}=3,56, \mathrm{OR}=4, \mathrm{TD}=4)$, kolay işlenmesi $(\bar{x}=3,51, \mathrm{OR}=4, \mathrm{TD}=4)$, kullanım olanakları $(\bar{x}=3,56, \mathrm{OR}=4, \mathrm{TD}=4)$, kaliteli işçilik ( $\bar{x}=3,56, \mathrm{OR}=4, \mathrm{TD}=4)$, müşteri talebi $(\bar{x}=3,67, \mathrm{OR}=4, \mathrm{TD}=4)$, dayanıklılık $(\bar{x}=3,62$, $\mathrm{OR}=4$, TD=4), görsellik ( $\bar{x}=3,61, \mathrm{OR}=4, \mathrm{TD}=4)$, geri dönüşümlü olması $(\bar{x}=3,58, \mathrm{OR}=4$, $\mathrm{TD}=4)$, çevre dostu olması $(\bar{x}=3,82, \mathrm{OR}=4, \mathrm{TD}=4)$ ve yenilenebilir olması $(\bar{x}=3,61, \mathrm{OR}=4$, $\mathrm{TD}=4)$, gibi özelliklerinden dolayı işletmeler tarafından tercih etme eğilimlerinin yüksek olduğu gözlenmiştir. İşletmelerin ahşap malzemeleri ekonomik olması $(\bar{x}=3,20, \mathrm{OR}=3$, $\mathrm{TD}=4)$ ve ahşap üreticisinin fazla olması $(\bar{x}=2,97, \mathrm{OR}=3, \mathrm{TD}=3)$ gibi özelliklerinden dolayı tercih etme eğilimleri ise orta düzeyde kalmıştır.

Çizelge 14. İşletmelerin ahşap malzeme kullanmayı tercih etme nedenlerinin incelenmesi

\begin{tabular}{|c|c|c|c|c|c|c|c|c|c|}
\hline $\begin{array}{c}\text { Ahşap malzeme kullanmayı tercih et } \\
\text { derecelendiriniz. }\end{array}$ & inizi & 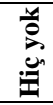 & 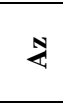 & 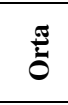 & 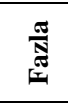 & نำ & Ort & OR & TD \\
\hline \multirow{2}{*}{ Ekonomik Olması } & $\mathrm{f}$ & 5 & 62 & 85 & 114 & 6 & \multirow{2}{*}{3.20} & \multirow{2}{*}{3} & \multirow{2}{*}{4} \\
\hline & $\%$ & 1.8 & 22.8 & 31.3 & 41.9 & 2.2 & & & \\
\hline \multirow{2}{*}{ Kolay Temin Edilmesi } & $\mathrm{f}$ & 2 & 42 & 69 & 121 & 38 & \multirow{2}{*}{3.56} & \multirow{2}{*}{4} & \multirow{2}{*}{4} \\
\hline & $\%$ & 0.7 & 15.4 & 25.4 & 44.5 & 14.0 & & & \\
\hline \multirow{2}{*}{ Doğal Olması } & $\mathrm{f}$ & 1 & 41 & 79 & 108 & 43 & \multirow{2}{*}{3.56} & \multirow{2}{*}{4} & \multirow{2}{*}{4} \\
\hline & $\%$ & 0.4 & 15.1 & 29.0 & 39.7 & 15.8 & & & \\
\hline \multirow{2}{*}{ Kolay İşlenmesi } & $\mathrm{f}$ & 2 & 42 & 76 & 119 & 33 & \multirow{2}{*}{3.51} & \multirow{2}{*}{4} & \multirow{2}{*}{4} \\
\hline & $\%$ & 0.7 & 15.4 & 27.9 & 43.8 & 12.1 & & & \\
\hline \multirow{2}{*}{ Kullanım Olanakları } & f & 2 & 47 & 67 & 109 & 47 & \multirow{2}{*}{3.56} & \multirow{2}{*}{4} & \multirow{2}{*}{4} \\
\hline & $\%$ & 0.7 & 17.3 & 24.6 & 40.1 & 17.3 & & & \\
\hline \multirow{2}{*}{ Ahşap Üreticisinin Fazla Olması } & $\mathrm{f}$ & 5 & 88 & 94 & 81 & 4 & \multirow{2}{*}{2.97} & \multirow{2}{*}{3} & \multirow{2}{*}{3} \\
\hline & $\%$ & 1.8 & 32.4 & 34.6 & 29.8 & 1.5 & & & \\
\hline \multirow{2}{*}{ Kaliteli İşçilik } & $\mathrm{f}$ & 3 & 46 & 68 & 106 & 49 & \multirow{2}{*}{3.56} & \multirow{2}{*}{4} & \multirow{2}{*}{4} \\
\hline & $\%$ & 1.1 & 16.9 & 25.0 & 39.0 & 18.0 & & & \\
\hline \multirow{2}{*}{ Müşteri Talebi } & $\mathrm{f}$ & 3 & 37 & 70 & 99 & 63 & \multirow{2}{*}{3.67} & \multirow{2}{*}{4} & 4 \\
\hline & $\%$ & 1.1 & 13.6 & 25.7 & 36.4 & 23.2 & & & 4 \\
\hline Davanıklılık & $\mathrm{f}$ & 1 & 43 & 67 & 108 & 53 & 362 & 4 & 4 \\
\hline & $\%$ & 0.4 & 15.8 & 24.6 & 39.7 & 19.5 & 3.62 & & 4 \\
\hline Görsellik & $\mathrm{f}$ & 5 & 46 & 59 & 101 & 61 & 361 & 4 & 4 \\
\hline Gorsell1K & $\%$ & 1.8 & 16.9 & 21.7 & 37.1 & 22.4 & 3.61 & 4 & 4 \\
\hline Geri D̈̈n̈̈сӥmlü $\Omega l m a s$ & $\mathrm{f}$ & 2 & 46 & 70 & 99 & 55 & 358 & 4 & 4 \\
\hline Gerı Donuşumıu Ulması & $\%$ & 0.7 & 16.9 & 25.7 & 36.4 & 20.2 & 3.58 & 4 & 4 \\
\hline & $\mathrm{f}$ & 2 & 30 & 56 & 112 & 72 & 382 & 4 & 4 \\
\hline Çevre Dostu Olması & $\%$ & 0.7 & 11.0 & 20.6 & 41.2 & 26.5 & 3.82 & 4 & 4 \\
\hline Yenilenebilir Olması & $\mathrm{f}$ & 3 & 42 & 68 & 105 & 54 & 3.61 & 4 & 4 \\
\hline Yenilenebilır Uimasi & $\%$ & 1.1 & 15.4 & 25.0 & 38.6 & 19.9 & 3.61 & 4 & 4 \\
\hline
\end{tabular}

Ort: Ortalama, OR: Ortanca, TD: Tepe değer, f: Frekans, \%: Yüzde

\section{Sonuçlar ve Öneriler}

$\mathrm{Bu}$ araştırma neticesinde elde edilen veriler değerlendirilmiş ve şu sonuçlara ulaşılmıştır;

- İşletmelerin ahşap malzemeler ile ilgili görüşleri incelendiğinde; işletmeler büyük oranda ahşap malzemeler hakkında yeterli bilgiye sahip olduklarını belirtmelerine rağmen ahşap malzemelerin kullanım olanaklarının yüksek olduğu düşüncesine istenilen oranda katılım sağlanmadığı düşünülmektedir. Aynı zamanda, azımsanmayacak bir oranda kararsız tutumların sergilendiği de görülmüştür.

- Firmaların malzeme tercihi durumlarına bakıldığında iç mekânlara kıyasla dış mekânlarda ahşap malzemeleri hem mobilya hem de yapı malzemesi olarak daha düşük seviyede tercih ettiği anlaşılmıştır. Aynı zamanda, işletmelerin müşterilerinin mobilya 
ve yapılarda malzeme tercihi veya taleplerinde müşterilerini olumlu ya da olumsuz etkileyebileceği düşünülmektedir.

- Genel anlamda, işletmelerin ahşap malzeme ile ilgili yapılan etkinlikler için yeteri kadar davet almadıkları ve katılım sağlamadıkları görülmüştür.

- İşletmelerin ahşap malzeme kullanmayı yüksek düzeyde tercih etme nedenlerinin arasında ilk sırayı çevre dostu olması alırken sonraki nedenler sırasıyla müşteri talebi, dayanıklılık, görsellik, yenilenebilir olması, geri dönüşümlü olması, kaliteli işçilik, kullanım olanakları, doğal olması, kolay temin edilmesi ve kolay işlenmesi almıştır. Ekonomik olması ve ahşap üreticisinin fazla olması ise orta düzeyde tercih edilme nedeni olmuştur.

- İşletmelerin ahşap malzeme kullanımını öğrenmek amacıyla hangi alanda hangi malzemeyi tercih ettiği incelenmiş, iç ve dış mekânlarda hem mobilya hem de yap1 malzemesi olarak masif ahşap malzeme ilk sırayı alarak en çok tercih edilen malzeme olmuştur. İşletmelerin iç ve dış mekânlardaki mobilya ve yapıların malzeme tercihinde belirli bazı malzemeler ile ilgili fikir birliğinde olup fazla düzeyde kullanım sağladığı görülmüş fakat genel anlamda malzeme tercihlerinde ise tercih sonuçlarının farklılık gösterdiği ve tutarsızlık oluştuğu anlaşılmıştır. Kullanım yerine göre malzeme tercihi yapılması konusunda bazı işletmeler tarafından doğru malzeme tercihlerinin yapılmadığı da görülmüştür.

\section{Teşekkür}

Bu makale, Selim Değirmentepe isimli yazarın doktora tezinden elde edilen bazı veriler ile hazırlanmıştır.

\section{Yazar Katkıları}

Selim Değirmentepe: Anketlerin yapılması, verilerin toplanması, makalenin yazılması, Mehmet Çolak: Araştırma fikrinin oluşturulması, anket sorularının hazırlanması, istatistik analizlerin yapilmasi,

\section{Kaynaklar}

Çolak, M., Değirmentepe, S., (2020), İç ve diş mekanlarda ahşap malzemelerin mobilya ve yap1 malzemesi olarak kullanımı, Türk Doğa ve Fen Dergisi, 9 (Özel Say1), 190-199. DOI: https://doi.org/10.46810/tdfd.789277

Değirmentepe S. (2020), İç mimarlık firmalarının ahşap malzemeyi mobilya ve yapı malzemesi olarak tercihlerinin belirlenmesi, Muğla Sitkı Koçman Üniversitesi, Fen Bilimleri Enstitüsü, Doktora Tezi.

Karasar, N., (1991). Bilimsel Araştırma Yöntemi, 4. Baskı, Sanem Matbaacılık, Ankara.

Kartal, B., (2015). Yapılarda ahşap kullanımı ve çağdaş yapı teknolojisinde ahşap kullanımı, Haliç Üniversitesi, Yüksek Lisans Tezi, İstanbul.

Kurtoğlu, A., Sofuoğlu, S.D., (2013), Mobilya ve ağaç işlerinde kullanılan ahşap malzemeler 1: Ağaç malzemelerin seçimi, işlenmesi, mobilya ve yapı elemanlarının üretiminde kullanılmaları, mobilya üretiminde kullanılan ağaç kökenli malzemeler, Mobilya Dekorasyon, 22 (118), 62-78.

Tavşancıl, E., (2005), Tutumların ölçülmesi ve SPSS ile veri analizi, 2. Baskı, Nobel Akademik Yayıncılık, Ankara. 